Fig. 26. Panorpa nebulosa, Westw. (Mecoptera), ventral.

Fig. 27. Panorpodes of Fig. 19, ventral.

Fig. 28. Nannochorista dipteroides, Tillyard (Mecoptera), dorsal view, based on Fig. 11 of Plate XVII, by Tillyard, 1917 (Proc. Linn. Soc. N. S. W.).

Fig. 29. Merope tuber, Newm. (Mecoptera), ventral. Gonopods cut off.

Fig. 30. Philopotamus Sp. n.? (Trichoptera), lateral.

\title{
NOTES ON TRIOZA ALACRIS FLOR IN NEW JERSEY.
}

By Harry B. Weiss and Edgar L. Dickerson. ${ }^{1}$

New Brunswick, N. J.

This Psyllid, which was introduced into New Jersey from Belgium and which is well known and destructive in Europe, has already been recorded as occuring in New Jersey (Weiss, Canadian Ent. Feb., 1917, pp. 73-75). D. L. Crawford in the Monthly Bulletin of the California State Commission of Horticulture Vol. I, No. 3, p. 86, gives an account of its presence in California together with suggestions for its control and also treats it in his Monograph of the Psyllidæ of the New World, Bull. 85, U. S. N. M.

It occurs in New Jersey on bay trees which are kept either under glass all the year or out of doors during the summer and under glass the remainder of the year. The following observations were made on trees kept outside during the summer months. Its presence on Bay (Laurus nobilis) can be readily detected by the curled, discolored, swollen, blistered leaves, usually at the tips of the branches, containing what appear to be whitish masses. Upon uncurling a leaf the nymphs are readily seen clothed in a white waxy secretion. In severe infestations the tree has a sickly and unwholesome appearance.

In New Jersey, the Psyllid overwinters as an adult on bay trees, which are kept in storage houses where the temperature is never allowed to go below 38 or 40 degrees F. About the middle or end of May according to the weather, the trees are moved outside and at is then when egg laying starts.

\footnotetext{
1 The arrangement of the authors' names has no significance and indicates neither seniority nor precedence.
} 
The minute, elliptical shaped eggs are laid on the under sides of young leaves near the margins, from 25 to 200 having been found in a single, elongated, irregular cluster. The leaves containing eggs were always found to be rolled in tightly and downwardly toward the midrib. The nymphs feed within the curled leaves and during the summer all stages of the insect can be found at the same time upon the same tree showing that egg deposition evidently extends over several weeks. The nymphs are covered over with white, waxy masses excreted from their bodies. Inside of a curled leaf can also be found globules of honey dew covered over with a waxy material and in many cases colonies of mealy bugs. The last stage nymphs move out of this sticky mess just before the adult is ready to emerge and rest on a drier and cleaner portion of the leaf just beyond the pseudo-gall.

About the middle of July adults of the first brood are appearing showing that about six weeks are required for a complete life cycle. About the first of September adults of a second brood can be found. These continue to appear for a month or so longer, even as late as November when the trees are in storage, provided the weather is not cold. The cool days during the fall undoubtedly prolong the numphal stages which are active only during warm weather and and this accounts for the delayed time over which the adults appear. These adults remain on the trees during the winter, many of them clustering around the pseudo-galls. On cold days they can be collected without difficulty on account of their dormant condition. On warm days during the winter the temperature of the storage house rises and at that time the adults are active when disturbed.

While contact insecticides are useful, it is impossible to reach the nymphs in the curled leaves which are protected still further by wax and.honey dew. In New Jersey almost complete killing was secured in one case by fumigating with tobacco smoke as for aphids while the trees were in storage and heavenly infested by overwintering adults. Hydrocyanic acid gas has also been used with success (See Review of Applied Entomology, Series A, Vol. II, p. 482). It is the practice of some firms to have their men go over infested trees and pick off all curled infested leaves, but this is a slow process in a large establishment.

Egg: Length $0.2 \mathrm{~mm}$., greatest width $0.1 \mathrm{~mm}$. Outline oval with distal end acutely pointed, rounded at basal end. Acute 
distal tip transparent, remainder opaque. Inserted in leaf tissue by means of a minute extension at basal end. One side rests close to leaf surface and becomes flattened. Other side is convex.

The following descriptions were made from alcoholic material.

First Stage Nymph: Length $0.21 \mathrm{~mm}$., greatest width $0.1 \mathrm{~mm}$. Color white; shape oval, broadly rounded at both ends, slightly sinuate at anterior margin; broadest across middle of thorax which gradually narrows at posterior extremity. Abdomen narrower than thorax. Body segmentation somewhat indistinct, that of abdomen indicated. Head, thorax and abdomen subequal in length. Body sparsely covered with minute hairs. Eyes indicated by red spots on lateral posterior margins of head. Antennæ length about one-third width of thorax, cone shaped, twice as long as width of base, tip slightly truncate; a minute spine arising from tip with a smaller one below. Legs, length, two-thirds the width of the thorax, gradually tapering toward tip; segmentation indistinct; apical end of leg bearing a sucker disc and a spine. Rostrum long, fine, hair-like; basal sheath extending to between bases of third pair of legs.

Second Stage Nymph: Length $0.3 \mathrm{~mm}$., greatest width $\mathbf{0 . 1 5}$ $\mathrm{mm}$. Color white; shape rectangular to broadly oval. Anterior end of body truncate, outer angles broadly rounded. Body gradually widening to posterior third of thorax, then gradually narrowing to posterior thoracic margin. Abdomen slightly narrower than thorax, posterior end rounded. Body sparsely hairy, segmentation indistinct. Antennæ cone shaped, length one-fifth width of thorax, outer extremity transversely ridged bearing two spines at tip. Legs similar to those of preceding stage except that they are proportionately larger and the sucker disc is missing. Tip of leg bears a pair of minute hooks. Eyes red. Basal sheath of rostrum extends to bases of second pair of legs.

Third Stage Nymph: Length $0.5 \mathrm{~mm}$., greatest width $0.22 \mathrm{~mm}$. Similar to second stage in shape and color except central dorsal portion of thorax and posterior margins of abdominal segments which are tinged with brown. Lateral margin of thorax bears a row of minute spines. A pair of these spines on lateral margin of each abdominal segment. Antennæ similar to those of preceding stage, length, one-sixth width of thorax. Eyes and legs similar to those of preceding stage. Basal sheath of rostrum extending to bases of second pair of legs. 
Fourth Stage Nymph: Length $1 \mathrm{~mm}$., greatest width $0.51 \mathrm{~mm}$. Color similar to that of preceding stage. Shape oval; truncate and sinuate at middle of front; outer angles of head broadly rounded. Division between head and thorax indicated by slight indentation at lateral margin. Thorax gradually widening to posterior portion where it is broadly rounded. Dorsal surface of head and thorax covered with a shield like expansion. Wing-pads visible and extending to posterior margin of thoracic expansion. Abdomen narrow at anterior margin, broadening to anterior fourth; remaining portion broadly rounded so that abdomen is almost circular in outline. A fringe of minute spines on lateral margins of head and thorax. Several spines on lateral margin of each abdominal segment. Eyes dark brown. Antennæ broadest at base, gradually tapering to tip which is slightly truncate. Antennæ more or less transversely ridged. Apical segment is one and one-half times the length of the basal segment. Tip of apical segment bears two spines. Legs three jointed, somewhat curved. The two basal segments are subequal in width, surface of second segment slightly convex, third segment slightly convex and tapering to tip which bears a pair of minute hooks. Legs bear a few minute scattered hairs. Basal sheath of rostrum extending to bases of second pair of legs.

Fifth Stage Nymph: Length $1.7 \mathrm{~mm}$., greatest width $1 \mathrm{~mm}$. General shape oval. Dorsal shield like expansion of head and thorax more pronounced. Head truncate in front, slightly convex, lateral margins broadly rounded. Front and anterior dorsal portion of head bearing a number of minute spines resting on minute tuberculate bases. Lateral expanded margins of thorax abruptly rounded from sides of head. Sides of thorax moderately convex extending to posterior margin of second abdominal segment. Wing-pads extending to posterior margin of shield like expansion. Lateral margin of prothorax bears a row of minute spines each resting on a minute tuberculate base; a few scattered minute spines on dorsal surface near margin especially in the anterior region. Sides of abdomen are convex making it broadly oval in outline. Abdominal segments well defined, lateral margins of each bearing a number of minute spines resting on minute tuberculate bases. A number of very minute spines on dorsal surface near margins. Eyes prominent, lateral, covered by dorsal expansion of head. 
Antennæ arising in front of eyes, apparently five jointed, length, four-fifths the width of the head; two basal segments covered by dorsal expansion of head. Antennæ transversely ridged; apical segment slightly club shaped, tapering to point and bearing two spines at tip and one on lateral margin. Legs three jointed; basal segment broadest, sides convex especially outer surface; second segment slightly longer than basal segment, sides parallel. Apical segment one-third length of second, slightly narrower; outer surface broadly rounded to inner forming tip terminated by a pair of hooks. Second and third segments bear a few scattered hairs. Basal sheath of rostrum extending to just beyond bases of first pair of legs.

Adult: Trioza alacris Flor, syn. Trioza lauri Targ. The following description is by Crawford (Bull. 85, U. S. N. M.). The original description by G. Flor appeared in "Zur Kenntniss der Rhynchoten Beschreibung neuer Arten der Familie Psyllodea Burm., Moskau, 1861." “Length of body $1.9 \mathrm{~mm}$., length of forewing 3.2, width of head 0.71. General color greenish yellow to light brown; dorsum in darker individuals more or less striped and streaked with brown; abdomen often brown; antennæ black at tip.

"Head nearly as broad as thorax, not strongly deflexed; vertex more than half as long as broad, emarginate in front at median line, with a prominent sulcate impression on each side of median line and parallel to it; genal cones scarcely two-thirds as long as vertex, divergent, subacute, pubescent, not much depressed from plane of vertex. Antennæ about one and one-third times width of head, slender. Thorax not broad, well arched, punctate; pronotum moderately long, not strongly depressed; præscutum rather large. Legs slender; hind tibiæ with two black spines at apex on inside and one outside. Wings long, slender, transparent, fully three times as long as broad, subacute at apex; Rs short.

"Genitalia-male-Anal valve a little longer than forceps, hind margin arcuate, with long pubescence; forceps rather stout, sides almost parallel (from sides), terminating in a subacute, black point at apex.

"Female-Genital segment nearly as long as rest of abdomen, acute at apex, valves subsequal in length." 

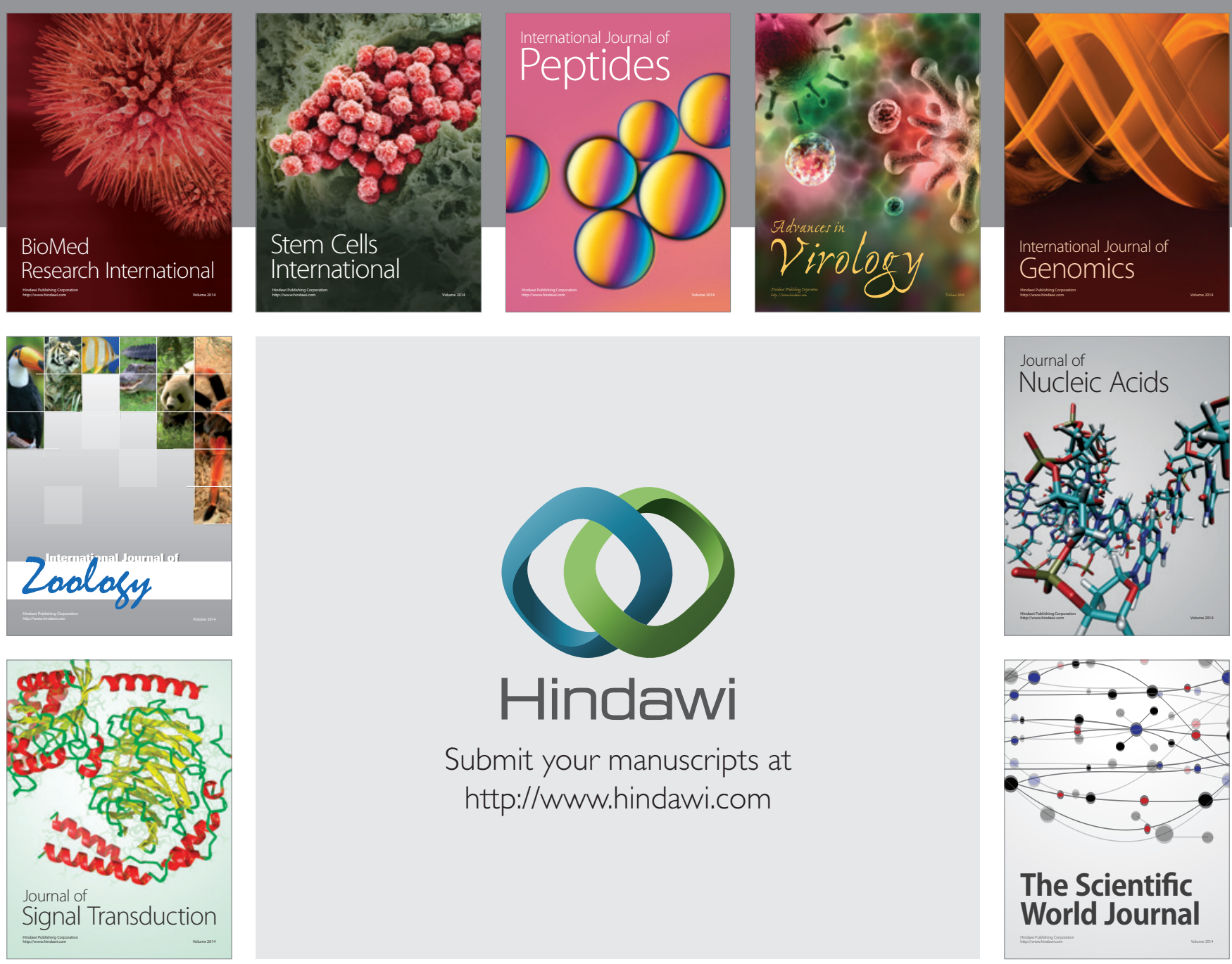

Submit your manuscripts at

http://www.hindawi.com
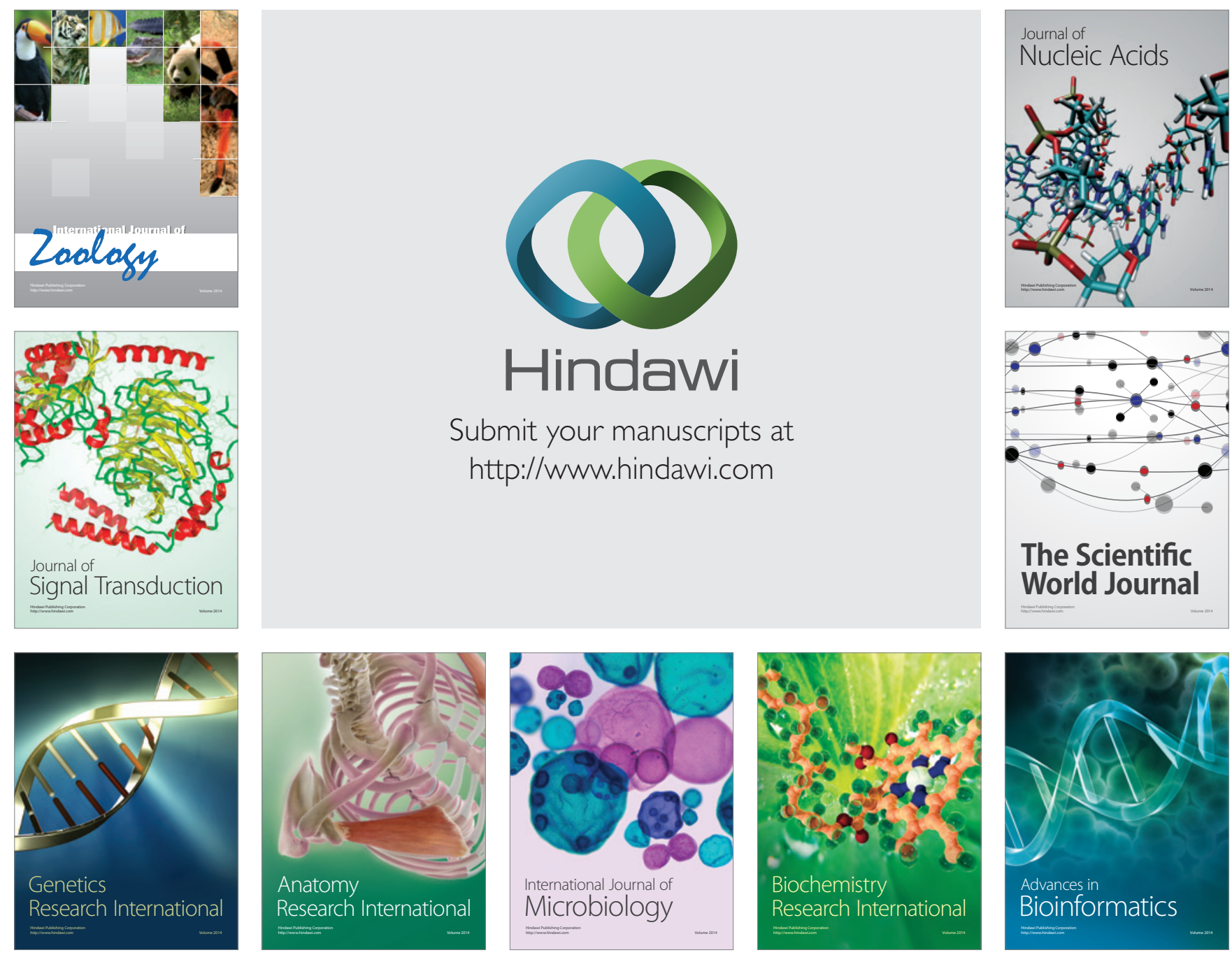

The Scientific World Journal
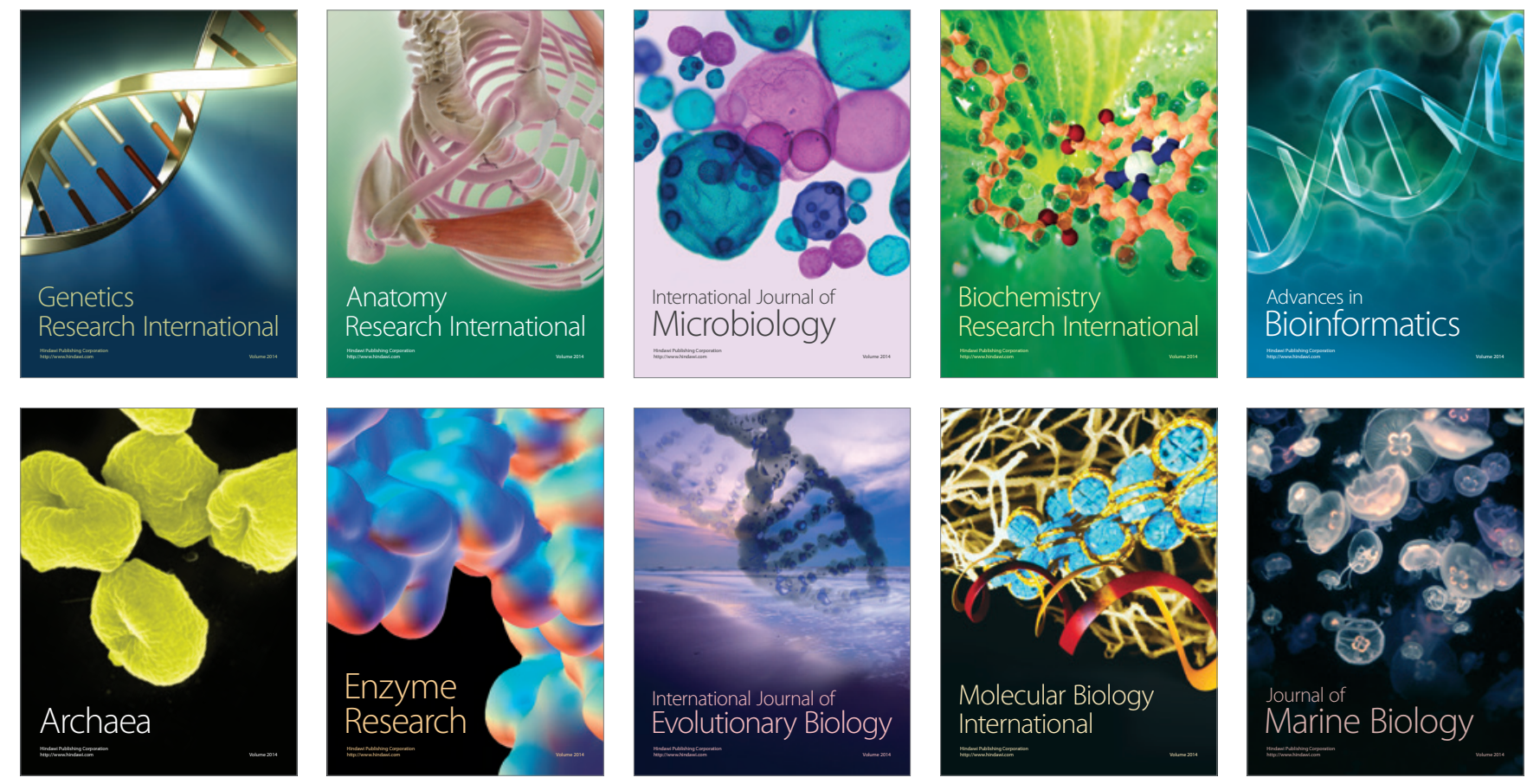